\title{
皮膚Staphylococcus の菌種プロフィルと 菌種間における抗生物質耐性菌の分布
}

\author{
A Species Profile of Skin Staphylococci and the Distribution of Drug \\ Resistant Strains among Five Antibacterial Agents in Staphylococcal Species
}

産業医科大学医療技術短期大学微生物

染 谷孝・茅原四郎

産業医科大学病院中央臨床検査部

田辺忠夫

Takashi Someya and Shiro Chihara

Department of Microbiology, School of Medical Technology, University of Occupational and Environmental Health, Kitakyushu

Tadao Tanabe

Department of Clinical Laboratory, School of Medicine, University of Occupational and Environmental Health, Kitakyushu

One hundred and forty-six strains of staphylococci were isolated from three exposed skin parts on the arm, forehead and crown of the head of 42 female junior college students. Isolated staphylococci were identified as the following ten species; S. aureus, S. simulans, S. xylosus, S. cohnii, S. haemolyticus, S. saprophyticus, S. warneri, S. hominis, S. capitis, S. epidermidis and unideitified staphylococci. Ninety-six percent of the isolated strains were coagulase negative staphylococci which were subdivided into $85 \%$ of S. epidermidis species group, $6 \%$ of $S$. saprophyticus species group and $3 \%$ of $S$. simulans as indicated by Kloos with the nuclear DNA homology of Staphylococcus species.

The sensitivity tests were carried out to isolated skin staphylococci with five antibacterial agents. PCG resistant staphylococci were 46 (32\%) of 146 strains, but high PCG resistant strains were not isolated. Staphylococci resistant to four other agents, KM, DOXY, EM, and CP were 4 (2.7\%), $12(8.2 \%)$, $11(7.5 \%)$, and $6(4.1 \%)$ strains respectively, and 9 of the EM resistances and 2 of the $\mathrm{CP}$ resistances were high resistant strains of MIC $\geqq 100 \mu \mathrm{g} / \mathrm{m} l$.

The same staphylococci of 146 strains were reinvestigated with a distribution of drug resistance in the above ten species. Comparisons were attempted with three divided groups of staphylococcal species; 62 strains of $S$. epidermidis, 38 strains of $S$. capitis and 46 strains of the remaining eight species. PCG resistant strains were recognized in $44 \%$ of the $S$. epidermidis and $37 \%$ of the eight species, but PCG resistant $S$. capitis was only recognized in $5 \%$ of the tested strains, corresponding to $1 / 4-1 / 5$ of the distribution ratios of the other two groups. Though KM resistant strains distributed in an equal ratio to each of the three groups, DOXY, EM, and CP resistant strains of S. epidermidis and S. capitis were only $1 / 3,1 / 7$ and $1 / 3$ of the distribution ratios of eight species. These results suggest that drug resistances are not evenly acquired and transferred among the species of skin Staphylococcus. 
Key words : Staphylococcus, Coagulase-negative, Staphylococci, Skin, Drug resistance ブドウ球菌，コアグラーゼ陰性，ブドウ球菌，皮膚，薬剤耐性

\section{諸} 言

人の皮膚のミクロフロラは, 皮膚常在菌と居住, 職業 など環境条件の影響を受け易い一過性の微生物によって 構成される。Noble \& Pitcher ${ }^{11}$ は皮膚 7 部位における 常在菌の構成が基本的には好気的および嫌気的グラム陽 性球菌，好気的および嫌気的 Coryneform bacteria，グ ラム陰性桿菌および酵母であると見なした。Kloos \& Musselwhite ${ }^{2)}$ は人体の皮膚 7 部位から採取した $M i$ crococcus 科の菌を分類学的に検討し Micrococcus 7 種, Staphylococcus11種の存在を明らかにした。即ち, Staphylococcus のうち分布の最も多い菌種にStaphylococcus epidermidis, Staphylococcus hominis, 比較的多い菌種 に Staphylococcus haemolyticus, Staphylococcus capitis, Staphylococcus aureus, 分布の少ない菌種に Staphylococcus saprophyticus, Staphylococcus cohnii, Staphylococcus xylosus, Staphylococcus simulans, Staphylococcus warneri と未同定の 1 菌株の存在を報告してい る。さらに Carr \& Kloos ${ }^{3}$ は, 生後32週までの乳幼児に ついて調查を行った結果，Staphylococcus は乳幼児の皮 膚にも広く分布していて, 成人と同様の 10 菌種で構成さ れていることを明らかにした。

最近, 寺山ら ${ }^{4)}$ は健康人から飛散して室内空中に浮遊 したStaphylococcus の菌種について検討し, S. epidermidis が $83 \%$ を占めていることを指摘した。この結果は 皮膚常在 Staphylococcus と室内空中Staphylococcus の 関連性を示唆している点で興味深い。

我々は, 本学女子学生 42 名を対象に腕, 額, 頭部の皮 膚からStaphylococcus146株を分離し, 検出された10菌種 について菌種間における分布比を求めた。また皮膚 Staphylococcus の抗生物質 PCG, KM, DOXY, EM, CP に対する耐性菌の分布調査を行い, さらに分離した10菌 種間における薬剤耐性菌の分布についても考察を加えた。 これらの結果を報告する。

\section{実 験 方 法}

\section{1）菌株の分離}

実験に使用したStaphylococcus 146 株は1982年 5 月か ら1983年10月の間に一般女子学生 30 名, 看護実習学生 12
名の腕・額・頭部の皮膚から採取した。Pブロス た滅菌綿棒で皮膚を擦り，これを $\mathrm{P}$ 寒天平板に塗布した 後 $35^{\circ} \mathrm{C}, 48$ 時間培養した。コロニーの性状およびグラム 染色標本の形態観察の結果からStaphylococcus と思わ れる球菌を 1 枚のシャーレから 2 株以上分離した。分離 菌株は P 寒天平板上で再度純化を行い実験に使用した。 菌株の保存は $50 \%$ グリセリン水に細胞を浮遊させ $-80^{\circ} \mathrm{C}$ に凍結して行った。

2) Staphylococcus 属および種の同定

分離したグラム陽性球菌のうちベンチジン試験陽性 ${ }^{6}$, カタラーゼ試験陽性菌を Micrococcus 科とした。運動性 試験陰性を確認した菌株についてはグリセロールーエリ スロマイシン培地における酸生成7), リゾスタフィンーリ ゾチーム感受性試験8), チオグリコレート培地における 嫌気的生育 ${ }^{9)}$ および glucose 発酵試験の結果から Staphylococcus 属を判定した。Staphylococcus と同定さ れた菌株についてはコアグラーゼ試験および Sta phylococcus 同定用キットAPI-STAPH (API System $\mathrm{SA})^{10)}$ を用いて種の同定を行った。

3）抗生物質感受性試験

感受性試験は, 日本化学療法学会規定（1981）による 最小発育阻止濃度 (MIC) 測定法 $\left.{ }^{11}\right) に$ 従って行った。感 受性試験には Müller Hinton 培地 (Difco) を使用し, P ブロスに培養した試験菌は $10^{6} / \mathrm{m} l$ に希釈して接種した。 菌の接種にはミクロプランター（MITF 型，佐久間製作 所）を使用した。抗生物質に対する標準感受性菌として S. aureus FDA 209P JC-1株を併用している。

4) 試薬

抗生物質は，各製薬会社から分与された $\mathrm{mg}$ 活性の表 示された製品を使用した。penicillin G（PCG，1590 U/ $\mathrm{mg}$ : 東洋醸造), kanamycin ( $\mathrm{KM}, 680 \mu \mathrm{g} / \mathrm{m} l$ : 明治製 菓) doxycycline (DOXY, $872 \mu \mathrm{g} / \mathrm{mg}$ : 台糖ファイザ 一), erythromycin (EM, $946 \mu \mathrm{g} / \mathrm{mg}$ : 塩野義製薬), chloramphenicol (CP, $996 \mu \mathrm{g} / \mathrm{mg}$ : 三共製薬)。

\section{実 験 結 果}

1）皮盧 Staphylococcus の菌種構成

一般女子学生30名から分離した75株と看護実習学生 12 名から分離した71株, 計146株の皮膚Staphylococcusに 
ついて菌種同定試験を行った。このうちコアグラーゼ陽 性菌は 6 株, 4 \%で, API-STAPH による性状試験の結 果からS. aureus と判定された。コアグラーゼ陰性 Staphylococcus は140株，全分離菌株の96\%であった。

Table 1 は，皮膚から分離されたStaphylococcus 10 菌 種と各菌種の分離菌株数を示す。Kloos ${ }^{12)}$ によって提示 された Staphylococcus 核 DNA homologyによる菌種区 分に従えば，分離されたコアグラーゼ陰性菌のうち $S$. epidermidis species groupは124株, 85\%で, S. saprophyticus species group は 8 株, $6 \%$ であった。この他 $S$. simulans 5 株， $3.4 \%$ と末同定の菌 3 株が分離された。 従ってコアグラーゼ陰性皮膚 Staphylococcus のうち約 90\%の菌株がS. epidermidis species group に属し, こ のうちS. epidermidis は62株と菌数が最も多く, S. capitis38株, S. hominis11株, S. haemolyticus 9 株と S. warneri 4 株が分離された。S. saprophyticus species group では S. saprophyticus, S. cohnii 各 3 株およびS. xylosus 2 株が分離された。

2）皮䖉Staphylococcus の抗生物質感受性

Table 1 Species profile of skin staphylococci.

\begin{tabular}{lcc}
\hline Species & No. of strains & $\%$ \\
\hline S. aureus & 6 & 4.1 \\
S. simulans & 5 & 3.4 \\
S. xylosus & 2 & 1.4 \\
S. cohnii & 3 & 2.1 \\
S. saprophyticus & 3 & 2.1 \\
S. haemolyticus & 9 & 6.2 \\
S. warneri & 4 & 2.7 \\
S. hominis & 11 & 7.5 \\
S. capitis & 38 & 26.0 \\
S. epidermidis & 62 & 42.5 \\
Unidentified & 3 & 2.1 \\
Total & 146 & \\
\hline
\end{tabular}

皮膚から分離したStaphylococcus146株の抗生物質 PCG, KM, DOXY, EM および CP に対する感受性試験 を行った（Table 2)。PCGでは標準感受性菌 S. aureus FDA 209P JC-1 に対する MIC 值の分布から MIC $\geqq 0.2$ $\mu \mathrm{g} / \mathrm{m} l$ の菌を耐性菌と見なした。試験菌146株中 46 株, $32 \%$ が PCG 耐性菌で, 3 株が MIC12〜25 $\mu \mathrm{g} / \mathrm{m} l$ を示 したが $\mathrm{MIC} \geqq 100 \mu \mathrm{g} / \mathrm{m} l$ の高濃度耐性菌は検出されな, かった。 KM, DOXY, EM, および CP の 4 剂について は $\mathrm{MIC} \geqq 6 \mu \mathrm{g} / \mathrm{m} l$ の $\mathrm{KM}$ 耐性菌 4 株 $(2.7 \%), \mathrm{MIC} \geqq$ $1.6 \mu \mathrm{g} / \mathrm{m} l$ の DOXY 而性菌12株 (8.2\%), MIC $\geqq 25 \mu \mathrm{g} /$ $\mathrm{m} l$ の $\mathrm{EM}$ 耐性菌11株 (7.5\%) と $\mathrm{MIC} \geqq 12 \mu \mathrm{g} / \mathrm{m} l$ の CP 耐性菌 6 株 (4.1\%) が分離された。このうち $\mathrm{KM}$ 耐性菌 4 株, EM 而性菌 9 株, CP 而性菌 2 株は MIC $\geqq 100 \mu \mathrm{g} /$ $\mathrm{m} l$ を示す高濃度耐性菌であった。

Table 3 Resistance patterns to PCG, KM, DOXY, EM, and CP of 146 strains of skin staphylococei.

\begin{tabular}{|c|c|c|}
\hline Resistance pattern & Frequency & of isolation, \% \\
\hline Non-resistance & 61.0 & \multirow{4}{*}{-28.1} \\
\hline PCG & 24.7 & \\
\hline DOXY & 0.7 & \\
\hline EM & 2.7 & \\
\hline PCG, DOXY & 2.7 & \multirow{8}{*}{-7.6} \\
\hline PCG, EM & 0.7 & \\
\hline PCG, CP & 0.7 & \\
\hline $\mathrm{KM}, \mathrm{DOXY}$ & 0.7 & \\
\hline $\mathrm{KM}, \mathrm{EM}$ & 0.7 & \\
\hline DOXY, EM & 0.7 & \\
\hline DOXY, CP & 0.7 & \\
\hline $\mathrm{EM}, \mathrm{CP}$ & 0.7 & \\
\hline PCG, KM, CP & 0.7 & \multirow{5}{*}{-2.8} \\
\hline PCG, DOXY, EM & 0.7 & \\
\hline PCG, EM, CP & 0.7 & \\
\hline DOXY, EM, CP & 0.7 & \\
\hline PCG, KM, DOXY, EM & 0.7 & \\
\hline
\end{tabular}

Table 2 Susceptibilities to five antibacterial agents of 146 strains of skin staphylococci.

\begin{tabular}{|c|c|c|c|c|c|c|c|c|c|c|c|c|c|c|c|}
\hline & \multicolumn{15}{|c|}{ No. of Strains } \\
\hline & \multicolumn{15}{|c|}{$\operatorname{MIC}(\mu \mathrm{g} / \mathrm{m} l)$} \\
\hline & 0.01 & 0.02 & 0.05 & 0.1 & 0.2 & 0.4 & 0.8 & 1.6 & 3 & 6 & 12 & 25 & 50 & 100 & $>100$ \\
\hline PCG & 30 & 48 & $9^{*}$ & 13 & 19 & 9 & 3 & 10 & 2 & & 2 & 1 & & & \\
\hline KM & & & & 1 & 34 & $73^{*}$ & 27 & 5 & 2 & & & & & 2 & 2 \\
\hline DOXY & 1 & & 8 & $39 *$ & 77 & 7 & 2 & 3 & 5 & 3 & 1 & & & & \\
\hline EM & & & & & & & & 9 & $79 *$ & 46 & 1 & 1 & 1 & 1 & 8 \\
\hline $\mathrm{CP}$ & & & & & & & 2 & 18 & $96^{*}$ & 24 & & & 4 & 2 & \\
\hline
\end{tabular}

* : Positions of MIC values for S. aureus FDA 209P JC-1. 
Table 4 Distribution of drug resistances in skin staphylococcal species.

\begin{tabular}{lcccccc}
\hline \multirow{2}{*}{ Species } & No. of strains & \multicolumn{5}{c}{ No. of resistant strains } \\
\cline { 3 - 7 } & & PCG & KM & DOXY & EM & CP \\
\hline S. capitis & 38 & $2(5 \%)$ & $1(3 \%)$ & $1(3 \%)$ & $1(3 \%)$ & 0 \\
S. epidermidis & 62 & $27(44 \%)$ & $2(3 \%)$ & $4(6 \%)$ & $2(3 \%)$ & $2(3 \%)$ \\
Total no. of the & 46 & $17(37 \%)$ & $1(2 \%)$ & $6(13 \%)$ & $9(20 \%)$ & $4(9 \%)$ \\
following 8 species & 6 & 4 & 0 & 0 & 0 & 0 \\
$\quad$ S. aureus & 5 & 3 & 0 & 1 & 0 & 0 \\
S. simulans & 2 & 0 & 0 & 0 & 1 & 1 \\
S. xylosus & 3 & 3 & 1 & 1 & 2 & 1 \\
S. cohnii & 3 & 2 & 0 & 0 & 0 & 0 \\
S. saprophyticus & 9 & 1 & 0 & 2 & 1 & 1 \\
S. haemolyticus & 4 & 1 & 0 & 0 & 1 & 0 \\
S. warneri & 11 & 3 & 0 & 2 & 3 & 1 \\
S. hominis & 3 & 0 & 0 & 0 & 1 & 0 \\
$\quad$ Unidentified & 146 & $46(32 \%)$ & $4(3 \%)$ & $11(8 \%)$ & $12(8 \%)$ & 6 (4\%) \\
Total & & & & & & \\
\end{tabular}

感受性試験の結果から 5 剂の抗生物質に対する多剤而 性のパターンおよび多剂耐性菌の菌株数を Table 3 に 示す。試験菌146株のうち多剤而性菌は16株で,このうち 2 剂而性菌は11株, 3 剂而性菌は 4 株, 4 剂耐性菌は 1 株であった。

3）皮膚Staphylococcus 菌種間における耐性菌の分 布

皮膚Staphylococcus の抗生物質感受性試験の結果, 試 験菌のうち $32 \%$ PCG 耐性菌で, KM, DOXY, EM, $\mathrm{CP} 4$ 剂の各々に対する耐性菌は試験菌の $10 \%$ 以下であ ったが， 5 剂の抗生物質夫々に対する耐性菌の分布には 菌種によってかなりの相違が認められた。この傾向を確 かめるため試験菌146株をS. epidermidis62株, S. capitis 38 株およびその他の 8 菌種46株の 3 群に分け, こ れら 3 菌群について各抗生物質に対する耐性菌の分布を 比較した (Table 4)。

PCG 而性菌は S. epidermidis で44\%，8 菌種で37\%の 菌株に認められたが, S. capitis では $5 \%$ であった。従っ て PCG 耐性 S. capitis の比率は S. epidermidis おょび 8 菌種で認められた而性菌の比率の $1 / 4 \sim 1 / 5$ であった。 $\mathrm{KM}$ 耐性菌の比率は 3 菌群で大差がなく, いずれも $3 \%$ 程度であった。しかしながら DOXY, EM, CP の 3 㓮に 対しては, いずれも 8 菌種で耐性菌の比率が高く, DOXY で13\%,EM で20\%, CP で $9 \%$ の菌株に耐性が認 められた。一方 DOXY, EM, CP 耐性 S. epidermidis お よびS. capitis は, 夫々 $3 \sim 6 \%, 3 \%$ 抢び $0 \sim 3 \%$ の 比率で検出された。従って DOXY, EM, CP の 3 用夫々
に対する耐性 S. epidermidis, S. capitis の分布率は 8 菌 種の $1 / 2 \sim 1 / 4,1 / 7$ おるび1/3であった。これらの結果は, 相互に比較した 3 群の菌が $32 \sim 58$ 株と比較的少数ではあ つたがStaphylococcus の菌種によって各抗生物質に対 する耐性菌の分布率に差異のあることを示唆するもので あった。

$$
\text { 考察 }
$$

Staphylococcus 属は霊長類その他哺乳動物の皮膚寄生 菌として知られているが12), このうちS. aureus, S. epidermidis は人 Staphylococcus 感染症の主な起因菌と なる。皮虐 Staphylococcus は squamae と共に脱落し空 気を媒体として伝播される ${ }^{1} 。$ 。最近の疫学的調査の結果 methicillin, gentamicin 耐性 S. aureus による院内感染 経路の一つとして医療従事者と患者の接触伝播の重要性 が指摘された ${ }^{13)}$ 。

女子学生32名の皮膚からStaphylococcus 146 株10菌種 を分離したが, この菌種構成はKloos らが人の皮膚 5 ケ 所から分離した結果 ${ }^{2)}$ と一致した。

分離菌146株のうち S. aureus, S. simulans を除くコア グラーゼ陰性 Staphylococcus 135株は, Kloos の呈示した groupingによれば12) S. epidermidis species group と, S. saprophyticus species group 2 group に区分され る。このうち S. epidermidis species group は124株, 全 分離菌の $85 \%$ で, S. saprophyticus species group は 8 株, $6 \%$ あっった。この結果を患者由来の検体 ${ }^{14)}$ および室 内 ${ }^{15)}$, 屋外空中 ${ }^{16)}$ から分離した Staphylococcus と比較す 
ると, 皮膚 Staphylococcus では S. epidermidis species group に属する菌の分布が著しく多い。

一般学生扔よび看護実習学生の皮膚から分離された Staphylococcus の菌種プロフィルには若干の相違が認め られた。後者から分離されたS. hominis は前者の $1 / 10$ 以下で，またS. simulans, S. xylosus, S. saprophyticus, S. warneri は後者から分離されなかった。この点につい ては, S. hominis の niche が毛囊の上層部にあると想定 されており,またS. simulans など 4 菌種の皮膚常在性 の少ないことも指摘されている ${ }^{17)} 。$ 実習終了後, 露出皮 膚部の浄化によって, これらの菌種が優先的に除去され た結果と考えた。

分離菌株の抗生物質感受性試験の結果 PCG 耐性は32 \%の菌に認められ, KM, DOXY, EM, CP 耐性菌はい ずれも $10 \%$ 以下であった。皮膚から分離された 10 菌種間 における耐性菌の分布比は, 分離菌株数の少ない菌種が 多いため, S. epidermidis62株, S. capitis 38 株とその他の 8 菌種46株の 3 群に区分し，5剤の抗生物質に対する耐 性菌の分布を 3 者間で比較した。その結果 PCG 耐性菌

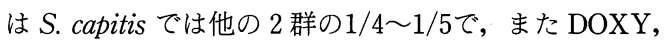
EM, CP 而性菌は S. epidermidis およびS. capitis で, 8 菌種の1/3 1/6であった。従って皮膚 Staphylococcus は 菌種によって薬剤而性の獲得, 伝播, あるいは耐性遺伝 子の脱落過程に相違のあることを示しているものと思わ れる。

Jaffe ら ${ }^{18)}$ は, gentamicin 而性および感受性 S. aur eus, S. epidermidis 相互間における而性 plasmid の伝達 を混合培養系で試験した。gentamicin 耐性 S. epidermidis をdonor とするとき耐性の伝達は S. aureus, S. epidermidis 両種に対してほぼ同率であるが gentamicin 耐性 S. aureus をdonor とすると耐性の伝達は同種の S. aureus に対してより効果的に行われることを見てい る。

Naido \& Noble ${ }^{19)}$ は S. aureus とコアグラーゼ陰性菌 S. hominis 而種間における gentamicin 耐性の伝達は, in vitro よりもむしろ人あるいはネズミの皮膚で効率よ く行われる事実を報告し，一般に病原性の点で明確さを 欠くコアグラーゼ陰性 Staphylococcus が薬剤耐性遺伝 子の carrier として関与している可能性を指摘した ${ }^{20)}$ 。

本研究では, 女子短期大学学生の露出皮虐に PCG 他 4 剤の抗菌薬剂に対する耐性 Staphylococcus の存在す ることを明らかにし，KM，EM，CPに対しては高濃度 耐性菌を検出した。これらの高濃度耐性を示す菌はすべ てコアグラーゼ陰性 Staphylococcus であった。薬剤而性
伝播の観点からみたコアグラーゼ陰性皮膚 Staphylococcus の果たす役割については, 更に検討を重ねる必要 がある。

\section{結吾語}

女子学生42名の皮膚（腕, 額, 頭部）から146株の Staphylococcus を分離した。これら菌株は, 同定しえなか った 3 株を除き, S. aureus, S. simulans, S. xylosus, S. cohnii, S. haemolyticus, S. saprophyticus, S. warneri, S. hominis, S. capitis, S. epidermidis のいずれかに同定 された。分離株の $96 \%$ はコグラーゼ陰性 Staphylococcus で, Kloosによる核 DNA 相同性にもと づく菌種区分に従えば，これらコアグラーゼ陰性菌の 85 \%が S. epidermidis 種グループ, $6 \%$ が S. saprophyticus 種グループ，4\%が S. simulans に区分された。

薬剤感受性試験を 5 剂の抗生物質について行った。 146株の Staphylococcus のうち, 32\%が PCG 耐性を示し たが, 高濃度 PCG 耐性菌は分離されなかった。 KM, DOXY, EM, CP に対する耐性菌は, それぞれ，4 株 $(2.7$ \%)，12株 (8.2\%)，11株 (7.5\%)，6株（4.1\%）認め られ,これらのうち $\mathrm{EM}$ 耐性菌 9 株および $\mathrm{CP}$ 耐性菌 2 株は, MICが $100 \mu \mathrm{g} / \mathrm{m} l$ 以上の高濃度耐性菌であった。

薬剤恧性の分布を菌種間で比較するために，供試した 10菌種146株の Staphylococcus S. epidermidis $(62$ 株), S. capitis (38株), およびその他の 8 菌種 (46株) の 3 群に区分して検討した。PCG 而性菌は, S. epidermidis で44\%， 8 菌種で37\%に認められたが，S. capitis ではわずか $5 \%$ \%であった。すなわち S. capitis における PCG 耐性菌の比率は, S. epidermidis および 8 菌種の場 合の $1 / 4 \sim 1 / 5$ であった。KM 而性菌の比率は 3 菌群で大 差がなかったが, S. epidermidis と S. capitis の DOXY, $\mathrm{EM}, \mathrm{CP}$ それぞれに対する而性菌の比率は，8 菌種の $1 / 3,1 / 7,1 / 3$ であった。これらの結果は, 薬剤而性の獲 得, 伝播の頻度が皮膚 Staphylococcus の菌種間で同率で は行われないことを示している。

謝辞

本研究の実施にあたり, 多大の御援助をいただいた味 の素株式会社ならびに各製薬会社に深謝いたします。

\section{文献}

1) Noble, W.C. and Pitcher, D.G.: In "Advances in Microbial Ecology, Vol.2” (Editor: M. Alexander), p. 245, Plenum Press, New York and 
London (1978).

2) Kloos, W.E. and Musselwhite, M.S. : Distribution and persistence of Staphylococcus and Micrococcus species and other aerobic bacteria on human skin, Appl. Microbiol., 30, 381-395 (1975).

3) Carr, D.L. and Kloos, W.E. : Temporal study of the staphylococci and micrococci of normal infant skin, Appl. Environ. Microbiol., 34, 673-680 (1977).

4）寺山和幸, 平田史子, 大野秀樹, 河原林忠男, 横田 正義, 青井 陽, 中田秀彦: Bacterial Aerosol に関 する研究, 第 9 報, 健康被験者から飛散した空中ブ ドウ球菌の抗生物質感受性, 日衛誌, 38, 677-682 (1983).

5) Nayler, H.B. and Burgi, E.: Observations on abortive infection of Micrococcus lysodeikticus with bacteriophage, Virology, 2, 577-593 (1956).

6) Deibel, R.H. and Evans, J.B. : Modified benzidine test for the detection of cytochrome-containing respiratory systems in microorganisms, J. Bacteriol., 79, 356-360 (1960).

7) Schleifer, K.H. and Kloos, W.E. : A simple test system for the separation of staphylococci from micrococci, J. Clin. Microbiol., 1, 337-338 (1975).

8) Schleifer, K.H. and Kloos, W.E. : Isolation and characterization of staphylococci from human skin. I. Amended descriptions of Staphylococcus epidermidis and Staphylococcus saprophyticus and descriptions of three new species: Staphylococcus cohnii, Staphylococcus haemolyticus and Staphylococcus xylosus, Int. J. Syst. Bacteriol., 25, 50-61 (1975).

9) Evans, J.B. and Kloos, W.E.: Use of shake cultures in a semisolid thioglycolate medium for differentiating staphylococci from micrococci. Appl. Microbiol., 23, 326-331 (1972).

10) Kloos, W.E. and Wolfshohl, J.F.: Identification of Staphylococcus species with the API STAPHIDENT system, J. Clin. Microbiol., 16, 509-516 (1982).

11）日本化学療法学会: 最小発育阻止濃度 (MIC) 測定 法再改訂について, Chemotherapy, 29, 76-79
(1981).

12) Kloos, W.E. : Natural populations of the genus Staphylococcus, Ann. Rev. Microbiol., 34, 559-592 (1980).

13) Crossley, K., Landesman, B. and Zaske, D. : An outbreak of infections caused by strains of Staphylococcus aureus resistant to methicillin and aminoglycosides, II Epidemiologic studies, J. Infect. Dis., 139, 280-287 (1979).

14）茅原四郎, 染谷孝, 田辺忠夫：臨床分離 Staphylococcus の薬剤感受性, 産業医科大学雑誌, 7, 373-379 (1985).

15）染谷孝, 茅原四郎：屋内空中に浮遊する Staphylococcus の菌種構成と薬剤感受性, 日本防菌 防徽学会第12回年次大会要旨集, 45-46 (1985).

16）茅原四郎, 染谷 孝：産業医科大学構内における大 気中の微生物の動態, 産業医科大学雑誌, 8 (特集 号), 27-37 (1986).

17) Kloos, W.E., Musselwhite, M.S. and Zimmerman, R.J. : In "Staphylococci and Staphylococcal Diseases, Proceedings of III International Symposium on Staphylococci and Staphylococcal Infections" (Editor: J. Jeljaszewicz), p.967, Gustav Fischer Verlag, Stuttgart and New York (1976).

18) Jaffe, H.W., Sweeney, H.M., Nathan, C., Weinstein, R.A., Kabins, S.A. and Cohen, S. : Identity and interspecific transfer of gentamicinresistance plasmids in Staphylococcus aureus and Staphylococcus epidermidis, J. Infect. Dis., 141, 738 -747 (1980).

19) Naidoo, J. and Noble, W.C.: Transfer of gentamicin resistance between strains of Staphylococcus aureus on skin, J. Gen. Microbiol., 107, 391-393 (1978).

20) Poston, S.M. and Naidoo, J.L. : In "Staphylococci and Staphylococcal Infections, Vol. I" (Editor: C.S.F. Easmon and C. Adlam), p. 63, Academic Press, New York and London (1983).

（受付 1986年 4 月 2 日 受理 1986年 5 月27日） 